\title{
DIFFERENT NITROGEN AND DOLOMITE APPLICATION INFLUENCE TO GLUTAMATE CONTENT OF CITRUS LEAVES (CITRUS HYSTRIX L.)
}

\author{
${ }^{1 *}$ Nunun Barunawati, ${ }^{1}$ Elfita Rahma Aulia, ${ }^{1}$ Adi Setiyawan \\ ${ }^{1}$ Agroecotechnology Study Program, Faculty of Agriculture, Brawijaya University Malang \\ *Corresponding e-mail: nnbaruna@gmail.com
}

\section{ABSTRACT}

The extend remobilization of nutrient on crops so far is known well. However, as we assumed that the re-translocation of the particular nutrient as nitrogen has a strong affect to the terpenoid metabolic like citronellol. In many cases, the environment stress such as drought induced volatile compound as citronellol leave in citrus. The aim of experiment is to observe the distribution of citronellol as consequence the distribution of nitrogen on different layer of tree canopy. The method of the research obtain the samples of leaves which were collected from different layer of citrus canopy from 10 samples of trees on each part of field: bottom layer, middle layer and upper layer of canopy. The randomized leaves were collected and analyzed by the HPLC and Spectro-photometer to measure the content of nitrogen and glutamate distribution correlated to citronellol content. The results presents that the closely correlation of distribution of nitrogen between bottom layer, middle layer and upper layer of lemon leaves to produce glutamate and citronellol. The remobilization of nitrogen from bottom leaves content $1.35 \mathrm{ppm}$ followed by middle leaves $1.4 \mathrm{ppm}$ and the highest is the upper leaves is $1.65 \mathrm{ppm}$. As consequence that the glutamate and citronellol were increase as the same trend as those nutrients distribution. The glutamate seems to be the precursor of the secondary metabolic which was converted into the harvested leaves of citrus. Increasing of 5\% glutamate from the upper leaves to the middle leave and the
\end{abstract}

bottom leaves seem to be much accumulated of citronellol content in the bottom leaves.

Key words: bottom leaves, middle leaves, upper leaves, citronellol, glutamate, nutrient distribution.

\section{INTRODUCTION}

Citrus hystrix $\mathrm{L}$ is one family of citrus grown in Indonesia. The citrus leaves harvested as row materials for pharmaceutical industry needs commonly as fresh leaves. However, the quality of secondary oil (from leaves) as a secondary metabolic production do not reported as well as their growth on different soil condition. The objective this experiment is to study the transportation of nutrient, particularly on nitrogen to produce the secondary metabolic (citronellol in citrus) and application of dolomite to increase $\mathrm{pH}$. There are differences between content of nitrogen to canopy leaves in term of citronellol as well as the organic matter production. It would be the fertilization particularly nitrogen is very important, following the age of plant and reproduction of new leaves after pruning. Based on research by Kamachi et al., (1991), remobilizes nitrogen accouted for $64 \%$ of the total nitrogent in the youngest leaf than in the older senescing leaves. Organic $\mathrm{N}$ has been translocated from sources to sinks by glutamine and glutamate (Campbell, 1999). In addition, the application of dolomite to stabilize of soil condition to increase $\mathrm{N}$ absorption. 


\section{METHODS AND APPROACH}

The research was conducted at field of Citrus hystrix L. in Kesamben Blitar East Java, on November-December 2018, which located $8^{\circ} 08^{\prime} 53.2^{\prime \prime S} 112^{\circ} 22^{\prime} 03.4^{\prime \prime E}$ at $190 \mathrm{~m}$ above sea level. Leaves were collected from 40 plants which age 4 year after planted. The sample leaves were pruned from three canopy layers to separates of leaves materials. (upper leaves, middle leaves and bottom leaves).

Each sample was taken about at $200 \mathrm{~g}$ on each layer per plant, and then collected sample leaves. The collected leaves repeated from 10 plants as the sample on each quadrant (North, South, East, West). The measurement included: Citronellol (total secondary metabolism) in leaves from three layer of canopy, the total nitrogen and glutamate on leaves, total nitrogen and organic acid material in soil, HPLC, Organic manure 50 ton/ha, $\mathrm{N} 100 \mathrm{~kg} / \mathrm{ha}$ and $50 \mathrm{~kg} / \mathrm{ha}$ dolomite.

Proline content was carried out by analyzing the proline content carried out on the leaves using a Spectro-photometer. Procedure for observing proline contents is preparation of ingredients. Making a solution of ninhydrin acid, ninhydrin acid was made by heating $1.25 \mathrm{~g}$ of ninhydrin in $30 \mathrm{ml}$ of the original glacial acetate and $20 \mathrm{ml}$ of $6 \mathrm{M}$ phosphoric acid until dissolved. Take 0.5 grams of fresh leaves pounded into a mortar and mashed. Grinded leaves in mortal were given a solution of $3 \%$ sulfosalicylic acid as much as $10 \mathrm{ml}$. Leaf solution and $3 \%$ sulfosalicylic acid filtered with filter paper Whatman no. $1.2 \mathrm{ml}$ of the filtrate was reacted with $2 \mathrm{ml}$ of ninhydrin acid and $2 \mathrm{ml}$ of glacial acetic acid in a test tube at $100^{\circ} \mathrm{C}$ for 1 hour.

The reaction ends by inserting a test tube in a goblet containing ice. The cold solution is extracted by mixing $4 \mathrm{ml}$ of toluene, then shake it with a vortex for 15-30 seconds to form two separate liquid layers. The toluene layer is red containing proline located at the top. The upper solution was taken using a pipette and measured amino acid levels with a spectrophotometer. The absorbance is read at a wavelength of 520 $\mathrm{nm}$. Amino acid levels are determined based on the reading of pure proline standard solution

\section{RESULTS AND DISCUSSION}

Table 1. Total Content of Nitrogen in Leaves at Different Layer of Canopy

\begin{tabular}{ccccc}
\hline Sample & North & South & West & East \\
\hline $\begin{array}{c}\text { Upper } \\
\text { leaves }\end{array}$ & $1,62 \mathrm{~g}$ & $1,60 \mathrm{fg}$ & $1,59 \mathrm{f}$ & $\begin{array}{c}1,58 \\
\mathrm{f}\end{array}$ \\
$\begin{array}{c}\text { Middle } \\
\text { leaves }\end{array}$ & $1,48 \mathrm{e}$ & $1,46 \mathrm{de}$ & $\begin{array}{c}1,45 \\
\mathrm{~cd}\end{array}$ & $\begin{array}{c}1,43 \\
\mathrm{c}\end{array}$ \\
$\begin{array}{c}\text { Bottom } \\
\text { leaves }\end{array}$ & $1,39 \mathrm{~b}$ & $1,38 \mathrm{ab}$ & $\begin{array}{c}1,37 \\
\mathrm{ab}\end{array}$ & $\begin{array}{c}1,36 \\
\mathrm{a}\end{array}$ \\
\hline BNJ 5\% & \multicolumn{5}{c}{0,02} \\
\hline KK $(\%)$ & 0,80 \\
\hline
\end{tabular}

In general, the upper leaves which was growth at north part, has the highest of nitrogen content per tree (Table 1) Those content of nitrogen and effect of dolomite strongly influence by mobile distribution of Nitrogen nutrient. In additional, it seems to be the field which placed at north part had the nitrogen content higher than others part (Figure 1). The distribution of nitrogen on upper part of leaves, had active of photosynthesis which has higher of glutamate. On the other hand, intense amino acid mobilization also happen during leaf senescence (Reis et al., 2009)

The application of nitrogen content following by increasing of $\mathrm{pH}$ in the soil attempt to absorb by plant and distribute on different of nitrogen in different layer of leaves, which is from upper to bottom. The highest content of nitrogen distribution which has concentration at $1.62 \mathrm{mg}$ g-1 in upper leaves. It was followed by the nitrogen content at middle and bottom leaves respectively at 1.48 and $139 \mathrm{mg}$ g-1. Thus, the content of nitrogen clearly influenced by the position of leaves but it is not affected by growing part of tree. 


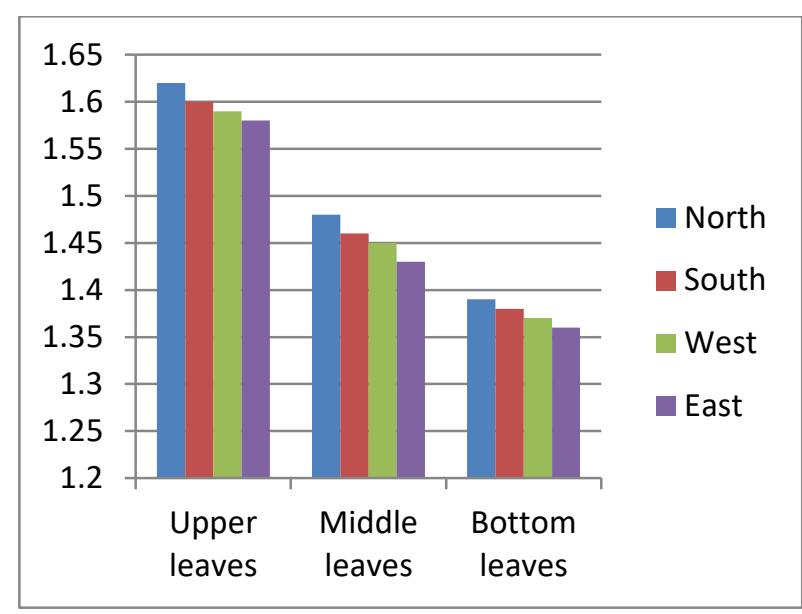

Figure 1. Total Content of Nitrogen in Leaves at Different Layer of Canopy

Based on the graph above, that the total of nitrogen in leave are difference among the leave which placed on upper, middle and bottom canopy (Figure 1). In upper leaves, the total nitrogen had the highest level compared to the total nitrogen in middle leaves and bottom leaves. It assumed that the distribution of nitrogen clearly depend on the layer of leaves on canopy regards to the character of nitrogen as a mobile nutrition. it assumed that the location of the old leaves in the bottom layer had reduce the nitrogen content while increasing it to upper and young leaves. Since the macronutrient (nitrogen) is a faster re-translocated than the micronutrient among the leaves (Taiz and Zeiger, 2010). As consequently, that the carbon cycle as the product photosynthesis process form the simple organic matter higher in bottom leaves and nitrogen accumulation higher concentration in upper leaves.

Moreno and Jose (2006) the translocation nitrogen from upper leaves until bottom leave is different following by the total content of protein. On the other hand, the nitrogen content as representative of protein in the old leaves decrease clearly and protein increase in the middle and upper leaves.
Table 2. Total Glutamate in Leaves at Different Layer of Canopy

\begin{tabular}{ccccc}
\hline Sample & \multirow{2}{*}{ North } & South & West & East \\
\hline Upper & \multirow{2}{*}{$34,73 \mathrm{i}$} & 34,23 & 33,71 & 32,76 \\
leaves & $\mathrm{hi}$ & $\mathrm{h}$ & $\mathrm{g}$ \\
Middle & $20,89 \mathrm{f}$ & 19,74 & 19,28 & 18,81 \\
leaves & e & $\mathrm{e}$ & $\mathrm{de}$ \\
Bottom & 22,95 & 21,15 & 20,50 & 20,10 \\
leaves & $\mathrm{cd}$ & $\mathrm{bc}$ & $\mathrm{ab}$ & $\mathrm{a}$ \\
\hline BNJ 5\% & \multicolumn{4}{c}{0,75} \\
\hline KK $(\%)$ & \multicolumn{5}{c}{11,39} \\
\hline
\end{tabular}

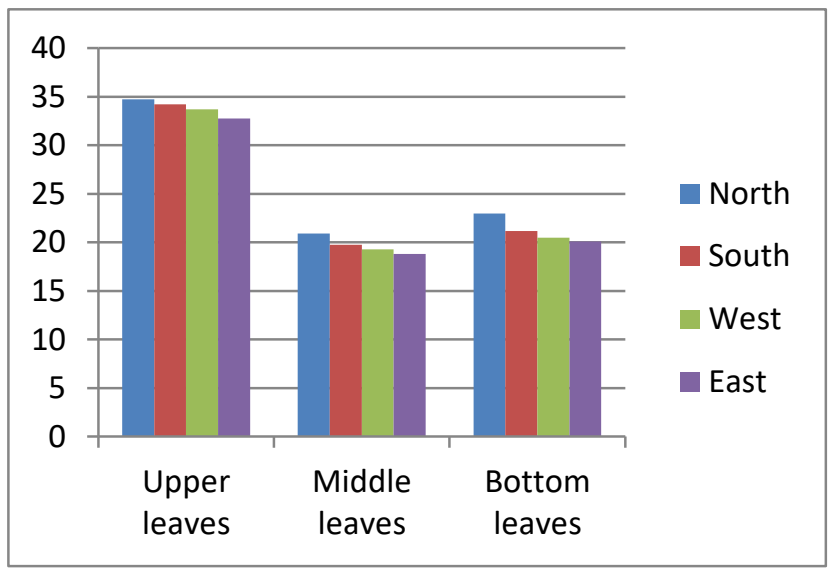

Figure 2. Total Glutamate in Leaves at Different Layer of Canopy

There are different total glutamate, as one of the protein, in leaves. Glutamate is the most abundant free amino acid in leaf at the fully expanded stage (Yamauchi et al., 1979). The highest total glutamate in leaves production by upper leaves, and then bottom leaves, and the lowest total glutamate production by middle leaves (Figure 2), The nitrogen can uptake by root is $\mathrm{NH}_{4}{ }^{+}$and then incorporated into glutamine and glutamate in the plastid or in the chloroplast by glutamine synthase and glutamate synthase in enzyme system. Supported by Hawkesford and Peter (2011), that root acquisition of nitrogen strongly stabilize of $\mathrm{pH}$ in the soil to remobilization and enhance of it absorption in to the plant. In bottom leaves decreasing uptake nitrogen will be increasing total glutamate in leaves (Callot, 1988). However, 
in this research total glutamate occurs in upper leaves highest since the metabolism of protein increase. Meanwhile, this can assumed increasing amino acid because increasing $\mathrm{N}$ supply and uptake by roots will be increasing amino acid in leaves.

Table 3. Total Organic Matter in Leaves at Different Layer of Canopy

\begin{tabular}{|c|c|c|c|c|}
\hline Sample & North & South & West & East \\
\hline $\begin{array}{l}\text { Upper } \\
\text { leaves }\end{array}$ & $50,82 b$ & $\begin{array}{c}50,70 \\
\text { b }\end{array}$ & $\begin{array}{c}49,78 \\
a\end{array}$ & $\begin{array}{c}49,47 \\
\text { a }\end{array}$ \\
\hline $\begin{array}{l}\text { Middle } \\
\text { leaves }\end{array}$ & $67,13 \mathrm{e}$ & $\begin{array}{c}65,88 \\
\mathrm{~d}\end{array}$ & $\begin{array}{c}65,26 \\
\mathrm{~cd}\end{array}$ & $\begin{array}{c}64,50 \\
\mathrm{c}\end{array}$ \\
\hline $\begin{array}{c}\text { Bottom } \\
\text { leaves }\end{array}$ & $69,13 \mathrm{~g}$ & $\begin{array}{c}68,56 \\
\mathrm{~g}\end{array}$ & $\begin{array}{c}68,00 \\
\mathrm{f}\end{array}$ & $\begin{array}{c}67,48 \\
\text { ef }\end{array}$ \\
\hline \multicolumn{2}{|c|}{ BNJ $5 \%$} & \multicolumn{3}{|c|}{0,85} \\
\hline \multicolumn{2}{|c|}{ KK (\%) } & \multicolumn{3}{|c|}{8,24} \\
\hline
\end{tabular}

On the other hand, the biosynthesis of organic matter, had the opposite to nitrogen and glutamate content. At the bottom leaves show (Figure 3) has higher organic matter content compared to middle and upper leaves.

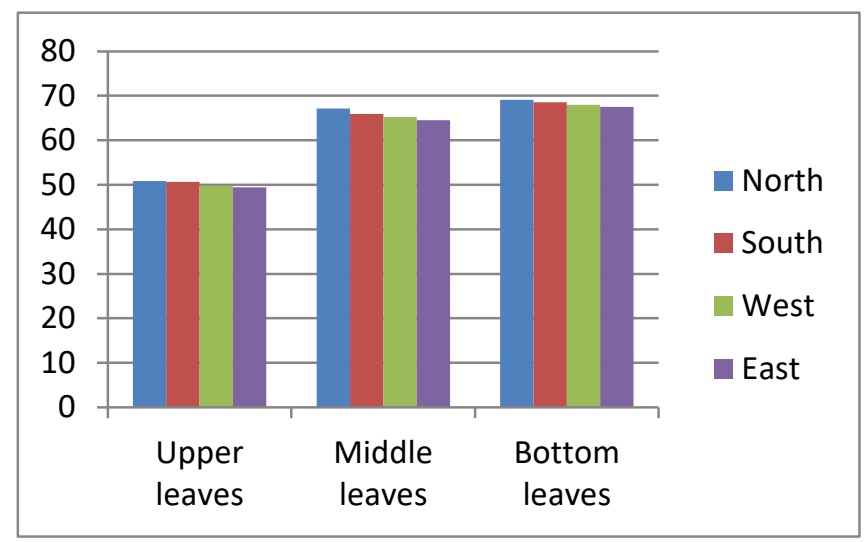

Figure 3. Total Organic Matter in Leaves at Different Layer of Canopy

The growing part of tree are also did not influence to total organic matter. Moreover the organic matter shows the higher on bottom leaves compared the middle and upper leaves (Picture 3). The higher on bottom leaves as results of increasing metabolism during the nitrogen re-translocated and reduced to carbohydrate and organic molecules. Organic matter likely related with increased productivity (Khan et al., 2013)

The organic matter as result of photosynthesis as the chelators to micronutrient absorption. It content was synergy increase in citronellol content. The macronutrient, nitrogen and the $\mathrm{pH}$ balance in the soil supported the citronellol synthesis. Acid produced when nitrification and decomposition of the organic matter can limit the increase in $\mathrm{pH}$ (Franchini et al., 2001). The bottom leaves with high organic matter which has high of secondary metabolic.

Table 4. Total Content of Secondary Metabolic at Different Layer of Canopy

\begin{tabular}{ccccc}
\hline Sample & North & South & West & East \\
\hline $\begin{array}{c}\text { Upper } \\
\text { leaves }\end{array}$ & $2,93 \mathrm{c}$ & $2,75 \mathrm{~b}$ & $\begin{array}{c}2,52 \\
\mathrm{ab}\end{array}$ & $2,31 \mathrm{a}$ \\
$\begin{array}{c}\text { Middle } \\
\text { leaves }\end{array}$ & $3,30 \mathrm{e}$ & $3,25 \mathrm{de}$ & $\begin{array}{c}3,19 \\
\mathrm{de}\end{array}$ & $\begin{array}{c}3,06 \\
\mathrm{~cd}\end{array}$ \\
$\begin{array}{c}\text { Bottom } \\
\text { leaves }\end{array}$ & $6,25 \mathrm{~g}$ & $6,19 \mathrm{~g}$ & $6,12 \mathrm{fg}$ & $5,94 \mathrm{f}$ \\
\hline BNJ 5\% & \multicolumn{4}{c}{0,23} \\
\hline KK $(\%)$ & \multicolumn{5}{c}{8,93} \\
\hline
\end{tabular}

Interestingly, the secondary metabolite as citronellol on the higher concentration in bottom leaves, following by those concentration in other leaves placed assumed that the organic compounds ready to be reduced into the last product (Figure 4). Those metabolism address to be re-translocate and storage into vacuoles in old leaves (bottom), The nutrients partitioned on the sink organs which required more vegetative growth. Indeed, the metabolism processes of carbohydrate reduction will be much take place on old leave or bottom canopy (Barunawati, 2013), The production citronellol tremendously application $\mathrm{N}$ fertilizer in soil of medium to low fertility. On Therefore, the citrus leaf respond to environmental condition by modifying their primary or secondary metabolism (Tanou et al., 2015). Initially 
high amounts of $\mathrm{N}$ could be applied to citronella crop, while at late stages, optimum levels of $\mathrm{N}$ could be fixed.

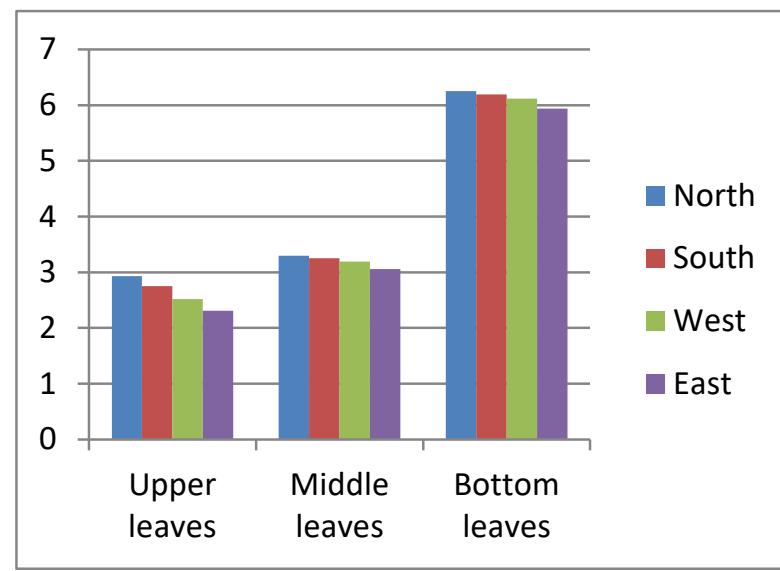

Figure 4. Total Content of Secondary Metabolic at Different Layer of Canopy

The data of nitrogen distribute in soil based on the graph shows that nitrogen content in soil at North growing region closely related to content of nitrogen in leaves.

The data total nitrogen in soil shows sloping in the other placed that the whole of field had the similarly concentration. In that case, the distribution of nitrogen and others nutrient in soil do not strongly effect to nutrient translocation in the similar layer of leaves. Thus, the production of citronellol in the citrus plants as well as the organic compound did not affected by the distribution of nitrogen and glutamate among the canopy (Figure 5).

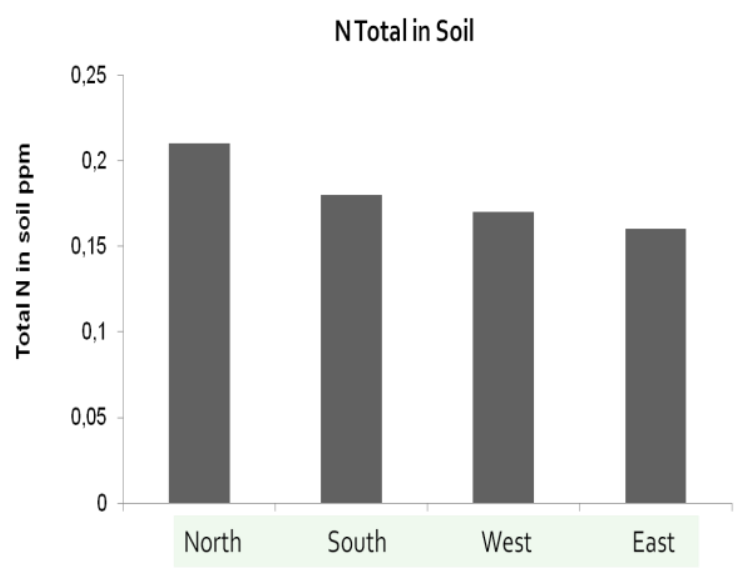

Figure 5. Total nitrogen in soil

\section{CONCLUSION}

The translocation of nitrogen and assimilation of glutamate did not affected by nitrogen content in the soil. Meanwhile, the secondary metabolic and organic matter clearly influenced by position of leaves in the layer are bottom, middle and upper. The bottom leaves had the lower of nitrogen and glutamate content but higher of secondary metabolic (assumed citronellol substrate).

\section{REFERENCES}

Barunawati, N., Ricardo F Giehl., Bernhard Bauer and Nicolaus von Wiren. 2013. The Influence of Inorganic Nitrogen Fertilizer Forms on Micronutrients retranslocation and Accumulation in Grains of Winter Wheat. J. Frontiers Plant Science (4):1-11.

Barunawati, Nunun. 2012. Iron and Zinc Translocation drom Senescent Leaves to Grains of Wheat (Triticum aestivum cv. Akteur) in Response to Nitrogen Fertilization and Citric Acid Application. Dissertation. MartinLuther-Universität Halle-Wittenberg.

Calot MC., Guerri J., Legaz F and Martin B., Primo-Millo E. 1988. Influence of Crop Load on The Composition of Free Amino Acids in Organs of Mature Valencia Late [Citrus sinensis (L.) Osbeck] Trees during The Growth Cycle. Paper presented at the Sixth International Congress, Balaban Publishers, Rehovot.

Campbell WH. 1999. Nitrate reductase structure function and regulation on bridging to gap between biochemistry and physiology. Ann Rev Plant Physio. 50:277-303.

Franchini, J.C., Gonzalez-Vila. F.J., Cabrera F., Miyazawa M and Pavan M. 2001. A. Rapid Transformations of Plant Water-Soluble Organic Compoundsnin Relation to Cation 
Mobilization in an Acid Oxisol. Plant Soil, v.231, p.55-63.

Kamachi, K., Tomoyuki Y., Tadahiko M., and Kunihiko O. 1991. A Role for Glutamine Synthetase in the Remobilization of Leaf Nitrogen during Natural Senescence in Rice Leaves. Plant Physiol (96): 411-417

Khan, S., Wang. N., Reid B.J., Freddo A and Cai C. 2013. Reduced Bio Accumulation of PAHs by Lactuca satuva L. Grown in Contaminated Soil Amended with Sewage Sudge and Sewage Sludge Derived Biochar. Environmental Pollution, v.175, p.6468.

Kutman, UB., Yildiz and I Cakmak. 2011. Effect of Nitrogen on Uptake, Remobilization, and Partitioning of Zink and Ion througot the Development of Durum wheat. J, Plant and Soil 342: 149-164.

Hawkesford, M.J and Peter B. 2011. The Molecular and Physiological Basis of Nutrient Use Efficiency in Crops. John Wiley \& Sons, Inc.

Marschner, P. 2012. Mineral Nutrition of Hingher Plants Third Edition, Academic Press. San Diego, USA. p 23-24.

Moreno, J and Jose GM. 2006. Nitrogen Accumulation and Mobilization in Citrus Leaves Throughout The Annual Cycle. Physiologia Plantarum 61(3): 429 - 434

Reis A.R., José L.F., Luiz A.G., Eurípedes M., Milton F.M and José L.J. 2009. Nitrate Reductase and Glutamine Synthetase Activity in Coffee Leaves During Fruit Development. R. Bras. Ci. Solo, 33:315-324, 2009

Taiz, L and Eduardo Zeiger. 2007. Plant Physiology 4th ed. Sinauer Associates, Berlin. p. 509-538

Tanou, G., Ziogas, V., Belghazi, M., Christou, A., Filippou, P., Job, D., et al. (2014). Polyamines Reprogram
Oxidative and Nitrosative Status and The Proteome of Citrus Plants Exposed to Salinity Stress. Plant Cell Environ. 37, 864-885.

Yamauchi, M., Ohashi T and Ohira K. 1979. Occurrence of D-alanylglycine in Rice Leaf Blades. Plant Cell Physiol 20: 671-673. 